\title{
Labour Regulations and Labour Standards in India: Decent Work?
}

\author{
Jens Lerche, School of Oriental and African Studies
}

\begin{abstract}
The article assesses the ILO decent work agenda in the Global South: its objectives and coherence, its impact on labour relations and conditions, and its overall policy direction in relation to alternative labour rights and welfare policy thinking. This is followed by a case study of the Indian version of the decent work agenda and the extent to which the ILO-India collaboration has influenced regulatory frameworks and labour relations. From this, wider lessons for both the ILO decent work agenda and for Indian labour relations are drawn: it is argued that the present emphasis on progress in social protection has inherent dangers as this is not likely to overcome underlying inequalities and form the basis for broader welfare coalitions, including for the political mobilization of informal workers themselves.
\end{abstract}

\section{KEYWORDS}

decent work, ILO, India, labour rights, social floor

\section{Introduction}

For more than a decade the ILO has trumpeted its new approach to informalized labour, the 'decent work' approach. Decent work is now the main policy objective for the international community with regard to labour. In 2006 it became part of the Millennium Development Goals and in 2010 even the IMF engaged with the decent work strategy (IMF 2010). By 2011 the ILO had entered into specific bilateral 'decent work' agreements with 61 countries. ${ }^{1}$ But how does this approach work out in relation to developing countries? That is the overarching topic of this article with a specific focus on the case of India.

India's interaction with the ILO goes back a long way. India was one of the founding members of the ILO and also, in more recent times, India's engagement with the ILO has been noticeable. Importantly, in February 2010 the Government of India effectively signed up to the decent work agenda by agreeing a five-year 'Decent Work Country Programme' with the ILO. 
The present article assesses the ILO decent work agenda: its objectives and coherence, its progress in international policy discourse, its impact on labour relations and conditions, and its overall policy direction in relation to alternative labour rights and welfare policy thinking. This will be brought to bear on the case of India, where the existing regulatory framework for labour relations will be discussed in relation to the reality on the ground. To what extent has the Indian version of the decent work agenda and the ILO-India collaboration influenced regulatory frameworks and labour relations? Who are the main social actors and what are the power relations delimiting their influence? What is the impact of the ILO on this? From this, wider lessons for both the ILO decent work agenda and for Indian labour relations will be drawn.

\section{Theoretical and Analytical Approaches Underlying the Decent Work Agenda}

The International Labour Organization is the UN agency responsible for international labour rights. ${ }^{2}$ The decent work agenda is the ILO umbrella strategy for improving the conditions of the working poor and those in vulnerable employment and, more broadly, for a 'fairer globalization'.

Conceptually, a set of categories developed by the ILO around this agenda stand out. These include 'informal employment', 'the working poor' and 'vulnerable employment'. The working poor are defined as people in work but also in poverty. Using the US\$ 1.25 and US \$2 a day poverty lines, the ILO estimates that in 2009 the working poor constituted around 21 percent and 39 percent of all workers around the world (ILO 2011a: 23-25). Workers in vulnerable employment are defined as own-account workers (i.e., self-employed) plus contributing family workers. The ILO states that this group tends to be in informal work arrangements, with inadequate earnings, low productivity and difficult conditions of work that undermine workers' fundamental rights' (ILO 2010a: 18). By 2009 half of all workers (50 percent) were estimated to belong to this category (ILO 2011a: 22-23).

According to the ILO, by far most working poor and workers in vulnerable employment are located within the informal economy. The 2002 ILO definition of the informal economy as encompassing both what the organization used to classify as the 'informal sector' as well as non-formal employment relations within formal sector firms, represents an important acknowledgement of the impact of flexibilization and informalization processes on work arrangements across the classic formal/informal sector divide. The ILO now understands 'workers' as straddling a number of different work arrangements. It argues that these work arrangements lead to, broadly speaking, similar outcomes for the workers in terms of vulnerability and poverty: self-employment in the informal economy, unpaid family workers, home workers within commodity chains, employees within the informal economy, employees without proper contracts in formal sector firms, workers employed through work contractors in formal sector firms etc. The ILO is also relatively clear regarding what has brought about these similarities, namely the present trends characterizing worldwide capitalist development (ILO 2002).

The ILO approach is very much in line with social democratic Keynesian ideology and draws on ideas not dissimilar from those of Karl Polanyi (Polanyi 1944). ${ }^{3}$ 
Labour per se is not exploited and the relentless accumulation drive of capital can be tamed by the state. Nevertheless there are also distinct parallels between the ILO conceptualization of labour today and that of a number of Marxist theorists who argue that, by now, all labour has been subsumed under capital. Dae-Oup Chang (2009) suggests that capital is dominant both within the 'global factory' of modern production but also that the society of today is 'permeated with the rule of value-producing capitalist labour': non-capitalist labour belongs to the past. At a more abstract level, Gibbon and Neocosmos argue with Marx that the fundamental wage labour-capital contradiction 'explain[s] the existence of classes at a general level' and of social groups 'indispensable to capitalism,' even if such groups differ from the 'canonical' wage labour type $(1985,156)$

- an analytical point repeated recently in an Indian context (Adduci 2009). In line with this, Bernstein argues that the ruthless capital accumulation in the South today has led to the creation of 'classes of labour', which include both classic wage labourers and those who depend more indirectly on the sale of their labour power. By this he encompasses all those who have to pursue their reproduction through insecure and oppressive - and typically increasingly scarce - wage employment and/or a range of likewise precarious small-scale and insecure "informal sector" ("survival") activity, including farming; in effect, various and complex combinations of employment and self-employment' (Bernstein 2007). Classes of labour thus can include those who possess some means of production but who, nevertheless, share with wage labourers the overall position of being exploited and oppressed - and who, indeed, may alternate between being wage workers and small-scale petty commodity producers seasonally or throughout their lifetimes.

The ILO perspective does not possess the analytical strength of the above political economy-based analyses of present-day capitalism but, nevertheless, it succeeds in identifying today's workers as broadly the same groups as these political economy analyses do. In Marxian terms, the capital-labour contradiction today is dominant, and other categories such as petty commodity producers (PCPs) should be understood in relation to this. Survival-level petty commodity producers in the informal economy (i.e., the bulk of the ILO category 'vulnerable employment') share the overall position of being exploited and oppressed with informal economy wage labourers, and they have little in common with the 'other end' of the PCP scale: namely, producers managing to invest in their company and move towards proper capitalist accumulation (see also Lerche 2010). ${ }^{4}$

\section{The Decent Work Agenda and its Implementation}

The decent work agenda represents the ILO 'fightback' in the 1990s. From the 1970s onwards, the neoliberal revolution swept away classic social democratic policies, labour market models and production organization and replaced them with flexibilization, informalization, deregulation, privatization, and de-unionization (see, for example: Kiely 2007, Munck 2004, Standing 2009). It is well established that neoliberalism changed decisively the balance of power between labour and capital, as a relatively 'labour friendly' welfare regime in the North was replaced with a 'labour unfriendly' regime, while in the South the 'development friendly' regime was being brought to an end (Silver and Arrighi 2000: 56, 61). As the international organization representing the classic social democratic welfare state compromise, the ILO was left in 
the wilderness as two of its three stakeholders, the employers and the dominant governments, directly attacked this compromise. In order to survive the ILO had to adjust to the new economic, social and political realities. It formulated its new policy approach based on an acceptance of the changes in the balance of power between labour organizations (unions and labour parties) and capital. As Ghai puts it on behalf of the ILO, the best labour movements can hope for in today's realities is to seek to influence policy makers. Direct action such as strikes belong to the past, as does policy making from a position of strength (Ghai 2006).

The weakened position of labour has had a major impact on the work that the ILO can undertake. From its founding in 1919 the ILO worked mainly through establishing international labour conventions which national governments faced pressure to sign up to. Once signed up, governments were legally required to implement the conventions, whilst being monitored by the ILO. Neoliberalism stalled this process, with employers and leading neoliberal governments blocking new conventions and seeking to roll back existing labour standards.

The decent work agenda broke this stalemate. Instead of seeking to establish new legally binding conventions this agenda focused on eight core conventions within a broad, non-binding framework concerned with 'fairness', 'decency' and other value-laden but imprecise descriptors. As the ILO general secretary put it, the precise levels of pay and conditions required and needed in order to achieve the 'decent work' stage were not to be fixed by the ILO. What mattered was a worldwide formal agreement 'to put in place a social floor for the global economy' (Somavia 2000, in Vosko 2002: 25-26). This new approach accepted the historic defeat of the classic ILO attempt to enforce social democratic labour standards internationally. However it also represented a welcome shift in focus of the ILO, away from unionized formal sector workers only towards unorganized workers in informal employment. Given the ILO's organizational makeup, where labour is represented by formal sector labour unions, this was not an easy shift and it still sits uneasily within the ILO setup (Vosko 2002; Standing 2008).

The four strategic objectives of the ILO 'decent work for all' agenda have remained constant since they were launched in the 1998 ILO 'Declaration on Fundamental Principles and Rights at Work':

1) Rights at work, grounded in fundamental principles of work and international labour standards

2) Employment and income opportunities

3) Social protection and social security

4) Social dialogue and tripartism (ILO 1998)

The eight core labour conventions that member countries were compelled to sign up to as part of the declaration were conventions against child labour and forced labour, and conventions for free collective bargaining and non-discrimination against groups of labour on the grounds of gender, race, religion etc. ${ }^{5}$ The decent work agenda also maintains a watered-down version of the classic ILO focus on social security, something which played a major role in ILO policies and conventions during the welfare state years. 
During the following decade the ILO developed and sharpened the decent work agenda. In 2004, it was given an explicit grounding in relation to globalization through a 'fair globalization' report and related follow-up policy processes (ILO 2004a). In 2006 it became part of the Millennium Development Goals. In 2009, the ILO constituents also agreed a 'global jobs pact' to further the decent work agenda at the time of the global downturn (ILO 2009a). ${ }^{6}$ Today, by far most governments have signed the eight core conventions and decent work has become part and parcel of the development policy discourse of both international organizations (UN, World Bank, IMF) and national governments. $^{7}$

However, the influence of the decent work agenda on conditions of work on the ground has remained fairly limited. The ILO has no powers of enforcement at its disposal, apart from 'naming and shaming' those in breach of conventions. Compared to the economic and political power of capital and of neoliberal governments, and even compared to the sanctions available to the WTO (the international agency charged with policing trade liberalization), the solely discursive powers of the ILO are extremely weak. At the international level no enforceable agreements have been reached concerning 'fair globalization' policies.

The existing long-term decline in the proportion of 'working poor' and of 'vulnerable workers' appears to mainly relate to economic growth and tightening of labour markets as well as to policies reflecting such labour market changes in countries such as China and Brazil. ${ }^{8}$ Only in one country - Brazil - can some of the improvements for workers be linked directly to the implementation of comprehensive decent work policies (Anderson 2011, China Labour Bulletin 2009, Sanchez-Ancochea and Mattei 2011: 306-7). Conditions at work for ordinary workers are barely mapped internationally, apart from quite general divisions between 'good jobs, poor jobs and no jobs', with national averages only drawn up in broad brushstrokes following per capita income levels (ILO n.d.d, Rodgers 2008).

Regarding the actual implementation of the 'declaration of fundamental principles and rights at work', most ILO effort has gone into the eradication of child labour. After some optimism in the early part of the twenty-first century, the ILO now cautions that the goal of ending the worst forms of child labour by 2016 may not be achieved (ILO 2010b). Eradication of forced labour is another ILO decent work priority area. While the ILO has succeeded in creating a fair amount of public awareness in this area, the actual impact is yet to be assessed (ILO 2009b, Lerche 2007).

The social security aspect of the decent work agenda has received a good deal of attention in recent years. In 2008 the UN committed itself to country-specific social protection floors consisting of a basic set of rights and transfers enabling access to a minimum of goods and services for all (ILO and WHO 2009: 1). This was confirmed and specified further by the ILO yearly International Labour Conference in 2011, and the 2012 conference aims to set international standards for social security (ILO 2011b; 2011c). This goes hand in hand with national policy developments. Social security coverage tends to improve with rising per capita income but with some significant variations between countries (ILO 2010c: 32-33). It also relates to global economic policies and realities: while neoliberal globalization and related policies initially led to a rolling back of (mainly employment-related) social security schemes (Gough 2003), 
developments in recent years have been more mixed with a number of countries reacting to the increasingly insecure employment conditions with improved social policy coverage. Case studies show that a crucial factor has been the underlying balance of power between social forces in the concerned countries (Kwon 2005, Ulriksen 2011). Also here, Brazil is one of the countries bearing the torch, with a comprehensive social security approach including cash transfers, which has contributed to successful poverty reduction in that country during the first part of the twenty-first century. Countries such as Chile and Mexico have registered progress in this area as well (Barrientos, Gideon and Molyneux 2008; Sanchez-Ancochea and Mattei 2011: 306-7). By 2010, and in many cases with support from the World Bank, all Latin American countries had introduced at least some targeted cash transfer schemes, as had some other countries, including China (Franzoni and Voorend 2011: 281, ILO 2010c, Sugyima 2011).

The ILO social floor agenda has rightly been commended for moving the international agenda away from ad hoc social safety nets towards the recognition of the need for a permanent social floor. Some even see cash transfers as the possible beginning of a new Polanyi-type countermove era based on the introduction of a 'social wage' for all (Standing 2009). Be that as it may, it is a clear lesson from the earlier history of the development of welfare states that for pro-poor policies to be politically sustainable they must move away from targeting only the poorest, towards becoming universal social and welfare policies. Only then will they receive firm backing from the middle classes and enable sustained improvement of poverty (Deacon and Cohen 2011. Haarstad and St. Clair 2011). Unless high levels of inequality are dealt with, the social floor policies will simply represent a new type of management of poverty while the balance of power remains as skewed as ever against workers and the poor, as Dion argues has been the case in Mexico (Dion 2010). An important element in this is the political mobilization of the poor independently of existing patron-client politics (Haarstad and St. Clair 2011). This means, among other things, that social floor policies cannot stand alone but will only effect change if accompanied by actions to deal with labour market-based income inequalities and, more specifically, in a context of organized social action by informal workers to improve their own lot (Deacon and Cohen 2011, Haarstad 2011).

Officially the ILO decent work agenda prioritizes both social floors and decent work. The increased ILO attention to social protection and social security in recent years may well reflect that progress at present seems possible only in this area. It also does not have a public position on whether it has got the balance between these policies right. Within the social floor policy area it explicitly does not have a view on the above discussion of targeted versus universal schemes (ILO n.d.e). It also does not engage in the general discussion of social alliances for the promotion of welfare programs in the longer run. We will return to these issues after the analysis of the Indian case.

\section{Decent Work in India}

In February 2010 the Government of India (GoI) and the Indian employers and workers organizations agreed a decent work program (DWP) with the ILO. The ILO hailed it as 'the biggest and most widespread DWP to be launched by the ILO and social partners in a country so far' (ILO 2010d). 
India could do with such a program as most work in this country is not at all 'decent'. By far most of the workforce (93 percent) is in informal work and by far most of the population (77 percent) survive on less than PPP\$ 2 a day (in 2004-05) (Sengupta et al. 2008). Informal and vulnerable work is increasing as formal labour is being replaced by informal labour and self-employment, the latter constituting 57 percent of the total workforce (2004-05). In the non-agricultural sectors this is due to a proliferation of small informal units and of informalized contract workers within formal sector firms, subcontracting to informalized firms, and increasing numbers of homeworkers. Selfemployment is not primarily an avenue of economic progress but mainly an activity undertaken where no suitable wage labour is available (Abraham 2009, Ghosh 2009, NCEUS 2009, Sengupta et al. 2008, Srivastava this volume).

The Decent Work Programme is aligned to the present Indian Five Year Plan (2007-2012). The program focuses on a) employment creation through skills development; b) continued extension of social protection for groups in the informal economy; and c) continued elimination of 'unacceptable forms of work'. No specific new government initiatives or activities are promised, but the ILO is to fund studies, technical support and capacity building and assist policy formulation in all the above areas - a good deal of which is already ongoing (GoI and ILO 2010).

It is interesting that the Indian Government has found it expedient to agree to the program. So far it has done little to get rid of 'unacceptable forms of work'. It has been argued that India 'probably has the most comprehensive legal structure for labour welfare and protection in the world' (Deshingkar 2009: 7). But the 93 percent of India's workers who are in informal employment do not form part of this. As the Indian government's National Commission for Enterprises in the Unorganised Sector (NCEUS) concluded, informal workers do not enjoy 'comprehensive protection of minimum conditions of work' (NCEUS 2009: 180). Most labour market laws only relate to formal sector firms, as establishments employing below a certain number of workers are exempt from them. This includes main labour laws such as the 'Factories Act' regarding health, safety and welfare of workers, the 'Industrial Employment Act' which deals with conditions of employment, and the 'Industrial Disputes Act' (Deshingkar 2009). The NCEUS (2007: 155-168) outlines the laws which apply to some sections of informalized labour. This includes the Minimum Wages Act, but the guaranteeing of (very low) minimum wages is rendered farcical by the fact that even the government's own employment programs are openly entitled to pay workers less than this stipulated amount (Sankaran 2011b). Informalized workers in enterprises with more than five workers employed should also be covered by the Inter-state Migrant Workmen Act which stipulates minimum conditions and pay for migrant workers and by the Contract Workers Act (when more than ten workers are employed) which regulate the market for cheap contract labour. The Bonded Labour System (Abolition) Act which outlaws forced labour and the Child Labour (prohibition and regulation) Act also cover informalized labour. Sector-specific legislation, not least for the construction and the beedi (country cigarette) industries, as well as some state-specific laws, are also of relevance for informal labour. However, as stated by the NCEUS, non-observation of all the above laws is endemic. For example, it has been calculated that ' 85 percent of all casual workers in rural areas and 57 percent of them in urban areas get wages below the minimum wages' 
(NCEUS 2007: 48). The labour law enforcement machinery is extremely thin on the ground and concentrates on formal sector inspections. It is exiguous since penalties tend to consist of minimal fines - for example, INR 500 (less than US\$ 7) for breaking the Minimum Wages Act (Sundar 2010a: 97). Presently the trend is towards further deregulation and simplification of labour laws and inspections, not towards the implementation of the existing regulatory framework, let alone making it more comprehensive for informalized workers (Sundar 2010b). To add insult to injury, none of the above regulations cover the 57 percent of Indian workers who are self-employed (NCEUS 2007: 155-168).

By now it should be clear that Government of India policies are far from aligned to the decent work agenda. In fact the government's own web pages are critical of the ILO agenda. The Ministry of Labour and Employment states categorically that the first objective of the Ministry is to achieve employment for 'any potential worker' and only afterwards is it appropriate to consider the quality of work - it is even stated that decent work will follow 'automatically' after employment has been achieved (GoI, n.d.). The ILO would agree that employment creation is an important part of the decent work agenda but it is a core aspect of the agenda that employment creation cannot be separated from the need to create decent work. Opposed to this, it appears that for the foreseeable future GoI wants to keep conditions of work in the informal economy as unregulated as they are today. This extreme rejection of the need to improve conditions of work, except at some point in the future, is opposed even by organizations such as the IMF (IMF 2010), and is also in direct contradiction to the objectives of the ILO - India Decent Work Country Programme.

Another contradiction is that GoI has only signed four of the eight core conventions that the decent work agenda requires. Forced labour and anti-discrimination conventions have been signed but child labour-related and social dialogue-related (right to organize and freedom of association) core conventions have not (EPW 2011, GoI n.d., ITUC 2007). National legislation in these areas is not fully in line with ILO conventions and the government has chosen simply not to sign the ILO conventions as opposed to amending the Indian legislation. That said, government and NGO implementation systems and development projects do exist regarding child labour and forced labour eradication, including some with ILO financial support, but their impact is limited. Official statistics show successes in dealing with child labour but this is disputed by NGOs and even by NCEUS (ILO 2010c: 23, ITUC 2011, NCEUS 2007: 165). Regarding forced labour, there has been no measurable success even though the legislation actually bans forced labour. The overall conclusion is that GoI does not seriously want to regulate labour markets in the informal economy with regard to conditions of recruitment, work and pay, not even regarding the worst forms of undecent work. It is in spite of this that the ILO has signed the decent work country programme with India, while quietly making an exception to the (very limited and very basic) formal minimum requirements of the decent work agenda in order to get India 'on board'?

The one area within the decent work agenda where India has taken significant initiatives is social protection, with three major initiatives. First and foremost, in 2005 the National Rural Employment Guarantee Act became law (NREGA or 'Mahatma 
Gandhi NREGA'). It guarantees 100 days of employment per year to one member of any rural household in government-funded local employment programs. While NREGA suffers problems such as corruption and only partial implementation, in the two first years it did manage to deliver on average 42 to 43 days of work to each participant (Mehrotra 2008). There are major regional variations in the implementation of the program, with those in power seeking to stop it in places, sometimes through violent means, and various social movements fighting for its implementation. Case studies also show that in places it has been successful in raising local wages across the economy (Dreze and Khere 2009, Banerjee and Saha 2010, Roy and Dey 2009). According to some, its impact can be seen in an overall increase in wages in the country (Chandrasekhar and Ghosh 2011). Others, however, dispute that the statistics indicate that such wage increases have occurred (Usami 2011). There is no doubt that rural workers have benefited from NREGA but even now, five years after its inception, its overall impact on the rural working poor is not clear.

The second main initiative is the social security bill which was passed in 2008. Its objective is to deliver social security to all workers. However, there is no timeline for its implementation, no dedicated government funds set aside for it, no built-in minimum universal entitlement to social security and it is left to each state to implement it as they see fit (Economic and Political Weekly editorial 2009, Sankaran 2009). Its limited impact is indicated by a recent survey of Indian government social policy and social expenditure by John Harriss. It shows that the combined central government and state government social expenditure has not increased in recent years in spite of these new programs (Harriss 2011: 134-5).

However, it is well known that Indian states, regions and even localities differ significantly in social policies and capacity and willingness to implement them (Harriss 1999; Kannan 2010). Specifically, southern states such as Kerala and Tamil Nadu are well ahead of most other states. For example, before the social security bill welfare funds existed for certain groups of unorganized workers in some states, especially in Kerala (where 57 percent of all workers are covered), but also in Tamil Nadu, Karnataka, Maharashtra, Madhya Pradesh, West Bengal and Tripura (Srivastava 2008: 120).

The third major initiative is the National Food Security Bill which the government, in December 2011, announced would be taken to parliament. It is a targeted program that would guarantee subsidized food grain to 75 percent of the population, with 46 percent of the rural population and 28 percent of the urban population receiving even cheaper food grain. (Himanshu and Sen 2011, Economic and Political Weekly editorial 2011). It would also move towards cash transfers instead of the actual provision of cheap food grain (Ghosh 2011). However, a number of states already have more universal provisioning of strongly subsidized food grain in place (Khera 2011).

Overall, Indian social policies take a non-universal approach. Of the programs, NREGA stands out as the one national social policy initiative which has importance in a pro-labour perspective, but it has not counteracted the increased inequality which has been documented, at least for the first decade of neoliberalism in India (1991-2002) (Jayadev et al. 2011). Compared to the Brazilian social programs its impact is clearly less.

The decent work-related policies in India are closely linked to the general relationship between workers, employers and the government in India. The Indian 
government is not the main driver of the decent work agenda. It is well documented that since the government's forceful suppression of the 1974 national railway strike it, and the Indian employers, have been on the offensive against organized labour while successfully seeking to informalize production and employment. The overt liberalization policies from 1991 onwards strengthened their hand even further. Today organized labour is reduced to negotiating from a position of weakness, mainly seeking to avoid job losses and cutbacks while informalized contract workers and self-employed workers are on the rise. Global competitiveness is, of course, an argument oft-used in support of such policies and it is indeed the case that a major export sector, such as the garment industry, is heavily informalized; but so too are domestic sectors such as, for example, construction. It is hardly surprising that workplace or wage-related actions by informalized labour are very rare and that organizations working with labour in informal employment often channel their efforts towards workers' access to government social schemes (Banerjee 2005: 123-5; Datt 2002; Ghosh 2002; Harriss-White 2003, 2010b; Harriss-White and Gooptu 2000; Lerche 2007; Lerche 2010; Mezzadri 2008; Picherit, this issue; Srivastava, this issue).

In this context social movements, academics and labour movements working with informal labour have been the main movers of decent work issues. Since the 1990s India has experienced concerted rights-based movements which have created political momentum for a variety of reforms, including rights to education and rights to information. The three major reforms detailed above are but the latest outcomes of the political pressure built up by such movements (Srivastava 2008). At the central political level these initiatives have been supported by the left wing parties and, more crucially, by a section of the ruling Congress party led by the Gandhi family who have long seen the need for the Congress party to have a social profile in order to be electable.

The specific social and economic context of the reforms was nearly a decade of agrarian crisis in the country (1997-2004). The withdrawal of government subsidies and credit as well as the collapse of output prices of certain crops led to low and even negative incomes for farmers in some parts of India. Politically most important perhaps, this led to a much-publicized increase in farmer suicides and it became a political imperative to be seen to react to the crisis (Lerche 2011, Ramachandran 2011, Reddy and Mishra 2009). NREGA was adopted by the Congress government after a sustained civil society campaign. Since then the National Commission for Enterprises in the Unorganized Sector - a commission set up after the joint Congress/Left election victory in 2004 and which had unusually strong ties to left-leaning activists and academics - has played a major role in making the decent work discourse relevant to the Indian context, to the extent where a critique of the Commission refers to 'NCEUS's Indian gospel of decent work' (Deshpande 2008). In 2006 it drafted a Social Security Bill, a rump version of which was eventually passed. Among other things it also developed a strategy for promoting decent employment (NCEUS 2009).

Outside government circles the decent work agenda and direct project funding and campaigning support from the ILO have been welcomed. The NCEUS has been working closely with the ILO. The ILO also interacts with academics and activists through workshops, conferences and ILO programs in India. There are many commonalities in the analytical points of departure of Indian Left political activists, 
intellectuals, union organizers working with informal workers and the ILO. For example, like the ILO, the activists also tend to see the self-employed as 'workers'. The fact that SEWA is registered as a Union for self-employed (women) is a case in point. So too are the NCEUS analyses and policy proposals for informal workers. These analyses are squarely based on an understanding of workers similar to the 'classes of labour' approach (NCEUS 2006, 2007, 2009). The 'working poor' concept is now in common usage in India, together with its homegrown variant: 'India's common people' developed by people within the NCEUS (Sengupta et al 2008). ${ }^{10}$

Practical and political links between the ILO and labour-related activists, scholars and organizations in India are numerous. In 2011 the ILO awarded the leading left wing Indian academic Jayati Ghosh the ILO Decent Work Research Prize. It routinely commissions background papers and policy analysis by Indian academics, fleshing out ILO policies in an Indian context. This includes papers on decent work (e.g. Ghosh 2008), social protection for Indian workers (e.g. Kannan 2004, and Unni and Ranai 2002), and on specific aspects of the decent work agenda such as forced labour (e.g. Srivastava 2005). ${ }^{11}$ In July 2010 the ILO South Asia Office website displayed ILOfunded India and South Asia specific publications and reports on issues such as employment creation strategies in India, industrial relations, the role of unions and movements in achieving decent work and the role of tripartite structures, all of which relate to the decent work agenda (ILO n.d.b). Indian social activists and academics are more than happy for the ILO to promote policies which they themselves seek to further vis-à-vis their own government. ${ }^{12}$

Both classic unions and new unions such as SEWA as well as movements such as the National Domestic Workers' Movement and the Fishworkers' Movement in India receive campaign assistance from the ILO, and campaign under the decent work banner (DISHA n.d., NDWDM 2010, WDDW 2009). This is part of a clear ILO strategy as the ILO argues that the actions of organized labour movements, including both unions and other movements, are necessary in order to achieve decent conditions of work and pay. The ILO helps to legitimize the demands of such movements.

Under these circumstances, the sign-up of the government to a Country Decent Work Programme can be interpreted in part as the result of pressure from civil society organizations and the ILO. It may be argued that the CDWP can provide further legitimacy for the decent work agenda and enable movements and unions to make use of this in their struggles.

For the ILO it is arguably important to have success stories to feed into its push for worldwide social floor policies. NREGA has become a central, non-Latin American, example of modern income security-related policies in the South, referred to by the ILO as 'one of the largest rights-based social protection initiatives in the world' (ILO 2010c). It is debated at ILO retreats (ILO 2011d), and is the object of ILO supported studies (ILO 2010e). However, as pointed out by Harriss-White (2010), there is a mismatch between the positive, if patchy, NREGA social floor policy, and the extreme lack of rights and extremely poor bargaining position of informalized labour regarding work conditions and employment relations. As stated above, a positive interpretation is that the NREGA floor will lead to an improvement of the bargaining position of labour, but as a generalized phenomenon this is yet to materialize. ${ }^{13}$ The question is whether the wish 
of the ILO to support Indian social floor policies is counterproductive for progress on other decent work-related polices in India? By entering into the DWCP the ILO criticism of the absence of government regulations regarding the terms and conditions of informal workers employment is significantly weakened.

\section{Conclusions}

The ILO has reacted to the changes that have occurred within the labouring classes' as part of the neoliberal drive towards flexibilization and informalization and its corresponding loss of influence and power. Its decent work approach has become the new main framework for international labour policies. Part of its strength is that it covers both work conditions and social floor policies but it remains that the ILO is without any meaningful means to enforce it.

In practice the decent work agenda has had little impact on the conditions of informal labour and even its focus on child labour and forced labour is yet to show major results. In the area of national social policies that there has been progress, especially in some Latin American countries where the dominant political coalitions have been sufficiently pro-poor. However, even in such countries the social policies lack depth and sustainability, as the social and economic basis for a continued alliance between the middle class and the poor is tenuous. As discussed earlier such alliances have classically formed the basis for more stable welfare regimes. They have coalesced both around social policies with universal coverage and which thus appeal across narrow social hierarchies, and around policies against inequalities in the labour market. This has created a common platform for welfare for workers and middle classes. The policies in Latin America have not been built in ways encouraging such alliances. The level of political mobilization among the working poor for the programs and against economic inequalities is also in its infancy. The development of crosscutting platforms and outright political mobilization is not part of the ILO decent work agenda and therefore leaves this agenda without sustained transformative power. This matters a great deal, even where the existing decent work agenda is far from being implemented in the Global South, because it has an impact on what to focus on within this agenda.

In India, conditions of work and pay are not improving for informalized labour. Labour finds itself in a very weak bargaining position, while government and employers push for further informalization. Social floor policies do exist, especially NREGA, but so far their impact on informal workers is patchy. Moreover, they are targeted as opposed to universal programs. There are also no policies aiming at dealing with economic labour market based inequalities.

The Indian political landscape also does not further the creation of broad propoor alliances. Social policies have been pushed through by middle class activists and by top-down initiatives, not by broad-based movements. Informal labour is not a political force to be reckoned with, neither in labour market relations nor in wider political contexts. This does not bode well for the sustainability of the alliance behind the social floor policies. The outcome of the existing policies is more likely to be 'management of poverty' than the creation of new social alliances that can carry through the decent work agenda in its entirety. 
There are pitfalls in leaving behind the workplace-related parts of the decent work agenda in the push for social floor policies; there are no guarantees that nonuniversal social floors will lead to overall improvements in decent work. In India organizations such as the NCEUS are aware of this and have argued for policies combining the introduction of a social floor with the generation of decent work for labour (NCEUS 2009). In India and elsewhere this, however, is not about to become government policy. The lesson for the decent work agenda is that it needs to treat work conditions, employment rights and social policy-related rights as interlinked so as to deal with the underlying social and economic inequalities. The absence of policies that can catalyze wider alliances on the ground is a threat to the possibility for political mobilization. The lack of efforts and initiatives seeking to deal with employment-related inequalities and to promote universal welfare programs, may well stall the progress of the agenda. Except, of course, if the existing targeted social floor policies actually do end up strengthening the bargaining position of wide sections of informal labour.

\section{NOTES}

1. By August 2011, the decent work country programs had reached 'final document' status in 61 countries, while 86 country programs were at preliminary stages (ILO n.d.a).

2. Its approach to labour issues is, by definition, consensual; something which is furthered by the fact that as the only UN agency it has a tripartite setup, with national governments, and employer and labour organizations as its three constituents.

3. The ILO 1944 Philadelphia Declaration statement, 'labour is not a commodity' is identical to Polanyi's view on labour, also published in 1944 (ILO 1944, Polanyi 1944).

4. It should also be recognized that, structurally, all positions in the production process held by members of the 'classes of labour' are not the same. As argued by Harriss-White, there are differences between PCPs and wage labourers. Most importantly PCPs are involved in more markets than wage labourers; namely in rent, interest and commodity exchange markets. It may also be that capital uses PCPs and wage labourers in different ways in the production process (Harriss-White 2010a: 3-4).

5. The eighth convention (ILO Convention No. 182 on the worst forms of child labour, 1999) was added when it was approved by the ILO a year after the initial announcement of the decent work agenda (Sankaran 2011a).

6. The ILO also came out in support of national minimum wages in 2008-9 (after a more subdued endorsement in 2004) (ILO 2004b, 2008-09). 
7. By January 2012, 135 countries had signed all eight core conventions; 18 had signed seven only and 30 had signed six or less (ILO n.d. c)

8. This decline has in fact slowed down since the onset of the financial crisis in 2008 (ILO 2011a: 21-25).

9. India was one of only four countries which opposed the 2010 ILO convention for domestic workers. The Indian domestic workers' movement declared this convention a 'major victory for domestic workers' (NDWDM 2010). The ILO has long supported the movement's campaign in India for government regulation of the conditions of work and pay of domestic workers (ILO 2009c).

10. That said, it should be noted that a different, out-and-out in favor of selfemployment view is prevalent among dalit political parties (e.g. the BSP) and among some dalit activist-intellectuals. This leads to the propagation of policies such as 'supplier diversity' - quotas within government procurement for SC/ST entrepreneurs which, if implemented, would lead to the strengthening of a class of SC/ST small-scale capitalists (Thorat and Sandana 2009). This is less relevant from a working poor perspective as it is well acknowledged that affirmative action is not particularly effective for poverty reduction as such policies tend to benefit the already better-off within the groups they are directed towards (Lerche 2008).

11. Ravi Srivastava and K.P. Kannan were two of the six members in charge of the NCEUS under the chairmanship of Arjun Sengupta.

12. See Lerche (2008) regarding this 'boomerang strategy' in relation to dalit movements in India.

13. More negative views of the social floor polices also exist. Harriss-White argues that in their present form they actually subsidize labour for capital (Harriss-White 2010b: 177); but so far there is little evidence in support of this hypothesis. Based on examples from Tamil Nadu, others argue that NREGA defuses the struggle for better pay and working conditions and exempts capital from responsibility to offer decent work conditions and pay (Vijaybaskar 2011).

\section{REFERENCES}

Abraham, V. (2009) 'Employment Growth in Rural India: Distress-driven?' Economic and Political Weekly 54(16): 97-107.

Adduci, M. (2009) 'Neoliberal Wave Rocks Chilika Lake, India: Conflict over Intensive Aquaculture from a Class Perspective', Journal of Agrarian Change 9(4): 484-511. 
Anderson, P. (2011) 'Lula's Brazil', London Review of Books 33(7). Available at: http://www.lrb.co.uk/v33/n07/perry-anderson/lulas-brazil (accessed 17 January 2012).

Banerjee, D. (2005) Globalization, Industrial Restructuring and Labour Standards. Where India Meets the Global. New Delhi: Sage Publications.

Banerjee, K. and Saha, P. (2010) 'The NREGA, the Maoists and the Developmental Woes of the Indian State', Economic and Political Weekly 45(28): 42-48.

Bernstein, H. (2007) 'Capital and Labour From Centre to Margins', Keynote address for conference on Living on the Margins. Vulnerability, Exclusion and the State in the Informal Economy, Cape Town, 26-28 March 2007. Available at: http://www.povertyfrontiers.org/ev_en.php?ID=1953_201\&ID2=DO_TOPIC (accessed 10 November 2011).

Chandrasekhar, C.P. and Ghosh, J. (2011) Public Works and Wages in Rural India: Macroscan. Available at: http://www.macroscan.org/fet/jan11/fet110111Public_Works.htm (accessed 10 November 2011).

Chang, D. (2009) 'Informalising Labour in Asia's Global Factory', Journal of Contemporary Asia 39(2): 161-79.

China Labour Bulletin (2009) Going it Alone. The Workers' Movement in China (20072008). Research reports http://www.clb.org.hk/en/files/share/File/research_reports/workers_movement_0 7-08.pdf (accessed 10 November 2011).

Das, S.K. (2008) 'Trade Unions in India: Union Membership and Union Density', The Indian Journal of Labour Economics 51(4): 969-82.

Datt, R. (2002) 'Industrial Relations - The Menacing Growth of the Phenomenon of Lockouts', in R.K. Sen, (ed) Indian Labour in the Post-liberalization Period (pp. 181-200). Kolkata: K.P. Bagchi.

Deacon, B. and Cohen, S. (2011) 'From the Global Politics of Poverty Alleviation to the Global Politics of Social Solidarity', Global Social Policy 11(2-3): 233-49.

Deshingkar, P. (2009) 'Extending Labour Inspections to the Informal Sector and Agriculture', Chronic Poverty Research Center Working Paper 154. London: Overseas Development Institution. 
Deshpande, L. (2008) 'NCEUS's Indian Gospel of Decent work', Indian Journal of Labour Economics 51(2): 287-98.

Dion M. (2010) Workers and Welfare: Comparative Institutional Change in TwentiethCentury Mexico. Pittsburgh: University of Pittsburg.

DISHA (n.d.) State Level Consultations on ILO Convention on Work in Fishing in Coastal States of India. Available at: http://www.dishaearth.org/Consolidated\%20Report\%20Consultations\%20on\% 20ILO\%20Convention.pdf (accessed 10 November 2011).

Drèze, J. and Khera, R. (2009) 'The Battle for Employment Guarantee', Frontline 26(1). Available online at: http://www.frontlineonnet.com/fl2601/stories/20090116260100400.htm (accessed 17 January 2012).

Economic and Political Weekly Editorial (2011) 'Food Security Bill: Simpler the Better' Economic and Political Weekly 46(52): 7.

Economic and Political Weekly Editorial (2009) 'Half-Step Forward', Economic and Political Weekly 44(1): 6.

Franzoni, J. and Voorend, K. (2011) 'Actors and Ideas Behind Chile, Costa Rica and El Salvador', Global Social Policy 11(2-3): 279-98.

Gibbon, P. and Neocosmos, M. (1985) 'Some Problems in the Political Economy of "African Socialism"', in H. Bernstein and B. Campbell (eds) Contradictions of Accumulation in Africa. Studies in Economy and State (pp. 153-206). London: Sage.

GoI (n.d.) India and the ILO. India Ministry of Labour and Employment. Available at: http://labour.nic.in/ilas/indiaandilo.htm (accessed 10 November 2011).

GoI and ILO (2010) Decent Work Country Programme India. Available at: http://www.ilo.org/global/About_the_ILO/Media_and_public_information/Feat ure_stories/lang--en/WCMS_123932/index.htm (accessed 10 November 2011).

Ghai, D. (2006) 'Decent Work: Universality and Diversity', in D. Ghai (ed), Decent Work: Objectives And Strategies (pp. 1-32). Geneva: International Institute for Labour Studies, ILO.

Ghosh, J. (2011) 'Cash Transfers as the Silver Bullet for Poverty Reduction: A Skeptical Note', Economic and Political Weekly 46(21): 67-71. 
Ghosh, J. (2009) Never Done and Poorly Paid. Women's Work in Globalising India. New Delhi: Women Unlimited.

Ghosh, J. (2008) 'New Research Questions in the Decent Work Agenda, A View From Asia', in G. Rodgers and C. Kuptsch (eds), Pursuing Decent Work Goals: Priorities for Research (pp. 39-48). Geneva: International Institute for Labour Studies.

Ghosh, S. (2002) 'Liberalization and Informal Sector: A Case-study of Footwear Manufacturing', in R.K. Sen, (ed.) Indian labour in the Post-liberalization Period (pp. 91-100) Kolkata: K.P. Bagchi.

Gough, I. (2003) 'Welfare Regimes in Development Contexts: A Global and Regional Analysis', in I. Gough, G. Wood with A. Barrientos, P. Bevan, G. Room, P. Davis Insecurity and Welfare Regimes in Asia, Africa and Latin America (pp. 15-48) Cambridge: Cambridge University Press.

Haarstad, H. (2011) 'Latin American Middle Classes and Political Mobilization for Universal Welfare', Global Social Policy 11(2-3): 229-31.

Haarstad, H. and St Clair, A. (2011) 'Social Policy and Global Poverty: Beyond the Residual Paradigm?', Global Social Policy 11(2-3): 214-19.

Harriss, J. (2011) 'How Far Have India's Economic Reforms Been "Guided by Compassion and Justice?" Social Policy in the Neo-liberal Era', in S. Ruparelia, S. Reddy, J. Harriss and S. Corbridge (eds) Understanding India's New Political Economy. A Great Transformation? (pp. 127-140). London and New York: Routledge.

Harriss, J. (1999) 'Comparing Political Regimes Across Indian States: A Preliminary Essay', Economic and Political Weekly 34(48): 3367-3377.

Harriss-White, B. (2010a) 'Globalization, the Financial Crisis and Petty Production in India’s Socially Regulated Informal Economy’, Global Labour Journal 1(1): 152177.

Harriss-White, B. (2010b) 'Work and Wellbeing in Informal Economies: The Regulatory Roles of Institutions of Identity and the State', World Development 38(2): 170-183.

Harriss-White, B. and Gooptu, N. (2000) 'Mapping India's World of Unorganised Labour', Socialist Register 2001: 89-118.

Himanshu and Sen, A. (2011) 'Why Not a Universal Food Security Legislation?', Economic and Political Weekly 46(12): 38-47. 
ILO (n.d.a) Decent Work Country Programmes. Available at: http://www.ilo.org/public/english/bureau/program/dwcp/countries/index.htm. (accessed 10 November 2011).

ILO (n.d.b) SRO New Delhi. Available at: http://www.ilo.org/public/english/region/asro/newdelhi/ (accessed 10 November 2011).

ILO (n.d.c) States Having Ratified Fundamental Conventions. Available at: http://webfusion.ilo.org/public/db/standards/normes/appl/applratif8conv.cfm?lang=EN (accessed 7 February 2012).

ILO (n.d.d) Measuring Decent Work. Available at: http://www.ilo.org/integration/themes/mdw/lang--en/index.htm (accessed 7 February 2012).

ILO (n.d.e) 'Universal and Categorical Schemes', GESS: Global Extension of Social Security. Available at: http://www.ilo.org/gimi/gess/ShowTheme.do?tid=3 (accessed 7 February 2012).

ILO (2011a) Global Employment Trends. Geneva: ILO. Available at: http://www.ilo.org/wcmsp5/groups/public/---dgreports/---dcomm/--publ/documents/publication/wcms_150440.pdf (accessed 10 November 2011).

ILO (2011b) Resolution Concerning the Recurrent Discussion on Social Protection (Social Security), International Labour Conference 2011, Geneva. Available at: http://www.social-protection.org/gimi/gess/ShowNews.do?nid=10007 (accessed 10 November 2011).

ILO (2011c) Social Protection Floors for Social Justice and a Fair Globalization, International Labour Conference, 101st Session, 2012, Report (IV)(1). Available at:

http://www.socialprotection.org/gimi/gess/RessShowRessource.do?ressourceId=2 4781 (accessed 10 November 2011).

ILO (2011d) Why Mahatma Gandhi NREGA in an ILO Retreat - Employment Policy Retreat, presentation 13 September 2011. Available at: ilo.org/emppolicy/events/WCMS_162788/lang--en/index.htm (accessed 10 November 2011).

ILO (2010a) Global Employment Trends. Geneva: ILO, January. Available at: http://www.ilo.org/wcmsp5/groups/public/---ed_emp/---emp_elm/--trends/documents/publication/wcms_120471.pdf (accessed 10 November 2011). 
ILO (2010b) Accelerating Action Against Child Labour. Report of the Director-General, International Labour Conference, 99th Session 2010, Report I(B). Geneva: International Labour Office. Available at: http://www.ilo.org/wcmsp5/groups/public/@dgreports/@dcomm/documents/pu blication/wcms_126752.pdf (accessed 10 November 2011).

ILO (2010c) World Social Security Report 2010-11: Providing Coverage in Times of Crisis and Beyond. Geneva: ILO. Available at: http://www.ilo.org/gimi/gess/RessShowRessource.do? ressourceId=15263 (accessed 10 November 2011).

ILO (2010d) Decent Work in India - A Triumph of Enterprise: Sitabai's Story. Available at: http://www.ilo.org/global/About_the_ILO/Media_and_public_information/Feat ure_stories/lang--en/WCMS_123932/index.htm (accessed 10 November 2011).

ILO (2010e) NREGA - A Review of decent Work and Green Jobs in Kaimur District in Bihar. Delhi office: 2010. Available at: http://www.ilo.org/newdelhi/info/WCMS_142539/lang--en/index.htm (accessed 10 November 2011).

ILO (2009a) Recovering From the Crisis: A Global Jobs Pact. International Labour Conference, Committee of the Whole on Crisis Responses, C.Pl./D.1 98th Session, Geneva, June 2009. Available at: http://www.ilocarib.org.tt/portal/images/stories/contenido/pdf/NEWS/2009/Rec overing $\% 20$ from $\% 20$ the $\% 20$ crisis $\% 20$ A $\% 20$ Global\%20Jobs\%20Pact $\% 20$ ILC \%2098th\%20Session\%202009.pdf (accessed 10 November 2011).

ILO (2009b) Global Report Under the Follow-up to the ILO Declaration on Fundamental Principles and Rights at Work. Report Of The Director-General, International Labour Conference, 98th Session 2009, Report I(B). Available at: http://www.ilo.org/wcmsp5/groups/public/---ed_norm/---

relconf/documents/meetingdocument/wcms_106230.pdf (accessed 10 November 2011).

ILO (2009c) Decent Work for Domestic Workers. Available at: http://www.ilo.org/wcmsp5/groups/public/---asia/---ro-

bangkok/documents/publication/wcm_041954.pdf (accessed 10 November 2011).

ILO (2008-09) Global Wage Report 2008-09 Minimum Wages and Collective Bargaining: Towards Policy Coherence, ILO. Available at: http://www.ilo.org/public/libdoc/ilo/P/09258/09258(2008-09).pdf (accessed 10 November 2011). 
ILO (2004a) A Fair Globalization: Creating Opportunities For All. World Commission on the Social Dimension of Globalization. Geneva: ILO.

ILO (2004b) The Minimum Wage: Catalyst for Social Dialogue or Economic Policy Instrument. The ILO Governing Body $291^{\text {st }}$ session, the $5^{\text {th }}$ item on the agenda. Committee on Employment and Social Policy. Available at: http://www.ilo.org/public/libdoc/ilo/GB/291/GB.291_esp_5_corr_engl.pdf (accessed 10 November 2011).

ILO (2002) Decent Work and the Informal Economy: Report of the Director-General, International Labour Conference, 90th Session; Report VI. Geneva: ILO. Available at: http://www.ilo.org/public/english/standards/relm/ilc/ilc90/pdf/repvi.pdf (accessed 10 November 2011).

ILO (1999) Decent Work For All in a Global Economy: An ILO Perspective. ILO Statement to the WTO meeting, submitted by Juan Samovia, Director-General International Labour Office, December 1999. Available at: http://www.hartfordhwp.com/archives/25a/053.html (accessed 10 November 2011).

ILO (1998) ILO Declaration on Fundamental Principles and Rights at Work, $86^{\text {th }}$ Session, Geneva, June $1998 . \quad$ Available at: http://www.ilo.org/declaration/thedeclaration/textdeclaration/lang--en/index.htm (accessed 10 November 2011).

ILO (1944) Declaration Concerning the Aims and Purposes of the International Labour Organization (Declaration of Philadelphia). Available at: http://www.ilo.org/ilolex/english/iloconst.htm (accessed 10 November 2011).

ILO and WHO (2009) Social Protection Floor Initiative. Manual and Strategic Framework for Joint UN Country Operations. Geneva: ILO and WHO. Available at: www.ilo.org/gimi/gess/RessFileDownload.do? ressourceId=14484 (accessed 10 November 2011).

IMF (2010) Oslo Conference Calls for Commitment to Recovery Focused on Jobs, Press Release No. 10/339, September 13, 2010. Available at: http://www.imf.org/external/np/sec/pr/2010/pr10339.htm (accessed 10 November 2011).

International Trade Union Confederation (ITUC) (2011) Internationally Recognised Core Labour Standards In India. Report for the WTO General Council Review of the Trade Policies of India. Geneva, 14 and 16 September 2011. Available at: http://www.ituc-csi.org/IMG/pdf/final_India_TPR_Report_3.pdf (accessed 10 November 2011). 
ITUC (2007) Internationally Recognized Core Labour Standards in India, Report for the WTO General Council Review of the Trade Policies of India. Available at: http://union.org.nz/sites/union/files/India\%20Core\%20Labour\%20Standards\% 20report_final-2.pdf (accessed 10 November 2011).

Jayadev, A., Motiram, S. and Vakulabharanam, V. (2011) 'Patterns of Wealth Disparities in India: 1991-2002', in S. Ruparelia, S. Reddy, J. Harriss and S. Corbridge (eds) Understanding India's New Political Economy. A Great Transformation? (pp. 81100). London and New York: Routledge.

Kannan, K.P. (2004) 'Social Security, Poverty Reduction and Development. Arguments For Enlarging the Concept and Coverage of Social Security in a Globalizing World,' Extension of Social Security Series, ESS Paper 21. Available at: http://www.ilo.org/gimi/gess/RessShowRessource.do?ressourceId=173\&longTitle $=$ Social + security $\% 2 \mathrm{C}+$ poverty+reduction + and + development\&author $=$ K.P.+Kann an\&ressYear=2004 (accessed 10 November 2011).

Khera, R. (2011) 'Revival of the Public Distribution System: Evidence and Explanations', Economic and Political Weekly 46(54-45): 36-50.

Kiely, R. (2007) The New Political Economy of Development. London: Macmillan.

Kwon, H. (2005) 'Transforming the Developmental Welfare State in East Asia', Development and Change 36(3): 477-97.

Lerche, J. (2011) 'Agrarian Crisis and Agrarian Questions in India. Review Essay.' Journal of Agrarian Change 11(1): 104-118.

Lerche, J. (2010) 'From "Rural Labour" to "Classes of Labour": Class Fragmentation, Caste and Class Struggle at the Bottom of the Indian Labour Hierarchy', in B. Harriss-White and J. Heyer (eds) The Comparative Political Economy of Development. Africa and South Asia (pp. 67-87). London: Routledge.

Lerche, J. (2008) 'Transnational Advocacy Networks and Affirmative Action for Dalits in India', Development and Change 39(2): 239-61.

Lerche, J. (2007) 'A Global Alliance Against Forced Labour? Unfree Labour, Neo-liberal Globalization and the International Labour Organization', Journal of Agrarian Change 7(4): 425-52.

Mehrotra, S. (2008) 'NREG Two Years On: Where Do We Go from Here?', Economic and Political Weekly 43(31): 27-35. 
Mezzadri, A. (2008) 'The Rise of Neo-liberal Globalisation and the "New Old" Social Regulation of Labour: The Case of Delhi Garment Sector', The Indian Journal of Labour Economics 51(4): 603-18.

Munck, R. (ed) (2004) Labour and Globalization. Results and Prospects. Liverpool: Liverpool University Press.

National Commission for Enterprises in the Unorganised Sector (2009) The Challenge of Employment in India. An Informal Economy Perspective. Volume I - main report. New Delhi: NCEUS, Government of India

National Commission for Enterprises in the Unorganised Sector (2008) A Special Programme for Marginal and Small Farmers. New Delhi: NCEUS, Government of India.

National Commission for Enterprises in the Unorganised Sector (2007) Report on Conditions of Work and Promotion of Livelihoods in the Unorganised Sector. New Delhi: NCEUS, Government of India.

National Commission for Enterprises in the Unorganised Sector (2006) Social Security for Unorganised Workers. Report. New Delhi: NCEUS, Government of India.

NDWDM (2010) Major Victory for Domestic Workers. Available at: http://www.ndwm.org/uploads/news/pdf/18_doc.pdf (accessed 10 November 2011).

Ramachandran, V.K. (2011) 'The State of Agrarian Relations in India Today', The Marxist 27(1-2): 51-89. Available at: http://www.cpim.org/marxist/201101agrarian-relations-vkr.pdf (accessed 7 December 2011).

Reddy, D.N. and Mishra, S. (eds) (2009) Agrarian Crisis in India. New Delhi: Oxford University Press.

Roy, A and Dey, N. (2009) 'NREGA: Breaking New Ground', The Hindu. Available at: http://www.hindu.com/mag/2009/06/21/stories/2009062150010100.htm (accessed 10 November 2011).

Rodgers, G. (2008) 'The Goal of Decent Work', IDS Bulletin 39: 63-68.

Sankaran, K. (2011a) 'Fundamental Principles and Rights at Work: India and the ILO' Economic and Political Weekly 46(10) 68-74.

Sankaran, K. (2011b) 'NREGA Wages: Ensuring Decent Work', Economic and Political Weekly 46(7) 23-25. 
Sankaran, T.S. (2009) 'A Critique of India's Unorganised Workers' Social Security Act, 2008', South Asia Citizens Web 16 February 2009. Available at: http://www.sacw.net/article658.html (accessed 10 November 2011).

Sanchez-Ancochea, D. and Mattei, L. (2011), 'Bolsa Familia, Poverty and Inequality: Political and Economic Effects in the Short and Long Run', Global Social Policy 11(2-3): 299-318.

Sengupta, A., Kannan, K.P., and Raveendran, G. (2008) 'India's Common People: Who are They, How Many are They and How do They Live?', Economic and Political Weekly 43(11): 49-63.

Silver, B.J., and Arrighi, G. (2000) 'Workers North and South', Socialist Register 2001: 53-76.

Sundar, K.R. Shyam (2010a) Labour Reforms and Decent Work in India: A Study of Labour Inspection in India. New Delhi: Bookwell.

Srivastava, R. (2008) 'Towards Universal Social Protection in India in a Rights-based Paradigm', Indian Journal of Human Development 2(1): 111-32.

Srivastava, R. (2005) Bonded Labour in India: Its Incidence and Pattern. Special Action Programme to Combat Forced Labour, Declaration/WP/43/2005, ILO: Geneva. Available at: http://digitalcommons.ilr.cornell.edu/forcedlabor/18/ (accessed 10 November 2011).

Standing, G. (2008) 'The ILO: An Agency for Globalization?', Development and Change 39(3) 355-84.

Standing, G. (2009) Work After Globalization: Building Occupational Citizenship. Cheltenham, UK, and Northampton, MA: Edward Elgar.

Sugiyama, N. (2011) 'The Diffusion of Conditional Cash Transfer Programmes in the Americas', Global Social Policy 11(2-3): 250-78.

Thorat, S. and Sandana, N. (2009) 'Caste and Ownership of Private Enterprises', Economic and Political Weekly 54(23) 13-16.

Ulriksen, M. (2011) 'Social Policy Development and Global Financial Crisis in the Open Economics of Botswana and Mauritius', Global Social Policy 11(2-3): 194-213.

Unni, J. and Rana, U. (2002) Insecurities of Informal Workers in Gujarat, India. Geneva: ILO. 
Usami, Y. (2011) 'A Note on Recent Trends in Wage Rates in Rural India', Review of Agrarian Studies 1(1): 149-182

Vijaybaskar M. (2011) 'Global Crises, Welfare Provision and Coping Strategies of Labour in Tiruppur', Economic and Political Weekly 46(22): 38-45.

Vosko, L. (2002) “"Decent Work” - The Shifting Role of the ILO and the Struggle for Global Social Justice’, Global Social Policy 2(1): 19-46.

WDDW (2009) World Day for Decent Work. Available at: http://www.wddw.org/Massmeeting-on-Decent-Work and http://www.wddw.org/A-call-for-decent-workfrom-India (Accessed 10 November 2011).

\section{BIOGRAPHICAL NOTE}

JENS LERCHE is Senior Lecturer in the Development Studies Department at the School of Oriental and African Studies (SOAS) of the University of London. His research interests include labour and the ILO, and labour, agrarian relations and caste in India. Recent publications include articles on work hierarchies and social mobilisation and on agrarian transition and agrarian crisis an Indian context. He is editor of the Journal of Agrarian Change. His present research is on labour conditions and the working poor in India and China. 